\title{
DISCUSSION ON THE PRECEDING PAPER
}

Air Cdre. G. L. McElligott (the President) thanked Dr. Wilkinson for reading the paper by Col. Willcox, who was at the time of the meeting in the United States of America, and proposed that any questions on it should be postponed until some future meeting at which Col. Willcox could be present. There might, however, be some members now present who had experience of conditions in West Africa, and their observations were invited.

The President had himself served with the Royal West African Frontier Force in World War I, and he, too, had seen self-inflicted "chancre" produced with the latex of the euphorbia tree. He remembered, too, seeing in Great Britain similar lesions produced by means of a patent cuticle remover.

Dr. Ashken said that he knew something of the difficulties which must be experienced with the West African native. He himself had been particularly interested in Nigeria, as he was in one of the hospitals there in 1941. One of their difficulties was that they were then not allowed to use any sulphonamides at all in treating the native ; use of the compound was limited entirely to European personnel, although later on they did manage to obtain a small supply for the use of the natives. He had had 200 beds in a 600 -bedded hospital for the treatment of the venereal diseases. Gonorrhoea was treated with intramuscular injections of T.A.B. vaccine, given each morning for 6-8 days. The African native, particularly in Nigeria, regarded gonorrhoea as one of the things which natives.either got or did not get. This attitude of indifference to the subject was one of the great obstacles to dealing with it, but he must say that he did not see any native in Nigeria who had not had gonorrhoea at one time or another.

The difficulties in treatment in West Africa were enormous. Col. Willcox had been fortunate in obtaining drugs, but when Dr: Ashken himself was there, the clinic was not even allowed to have its own syringes, everything which they used having to be borrowed from the surgical department. They gave local irrigations by means of tubes fitted with home-made nozzles. Many of the soldiers whom he saw suffered from yaws. When the native soldier found that he could get out of the Army because of any disease affecting the feet, he was much inclined to bring about an imitation of the disease, even to using hot cinders for the purpose, making holes in the soles of his feet.

Dr. E. E. Prebble said that he was greatly relieved to hear that the treatment by injection of sulphapyridine had ceased. He had seen quite a number of West Africans who were suffering from lymphogranuloma, and he was much surprised to hear that they had responded to penicillin. He had tried penicillin in varying dosages, and he was sorry to say that he had not seen one single case respond. Some of the patients had buboes which were broken down and obviously had become secondarily infected; these did show some degree of improvement, but the actual granulomatous condition did not respond in any way.

Dr. F. C. Doble said that he went to Uganda in 1913, at a time when 90 per cent of the natives of that country were suffering either from syphilis or from yaws. He had taken with him small quantities of " 606." It was only with the greatest difficulty, however, that the na persuaded to come for treatment, because they were afraid that they would go blind, as had happened in so many cases after treatment with Atoxyl (sodium arsanilate) for sleeping sickness. He had partly persuaded them by getting some "big chiefs" to bring their wives, some of whom had suffered for many years from yaws. The results were gratifying, for instead of being covered from head to foot with septic sores they began to look wonderfully better.

The difference between gonorrhoea in the native and in the white man was a curious one. In the white planter there was swelling of the joints and pain on micturition, whereas in the native the clinical picture took a different form, with no pain and few complications.

The President said that West Africa was by no means the only reservoir of infection. There were enormous reservoirs in the Far East-in Singapore, Hongkong, and Rangoon-as well as much nearer home, on the Continent of Europe. Many soldiers who had been serving on the Continent and had contracted syphilis came home and unknowingly infected their wives, not infrequently during the incubation period.

\section{Ambrose Paré as a syphilologist}

At a meeting of the Société Francaise de Dermatologie et de Syphiligraphie, reported belatedly in the number for 10th February 1946 of Bruxelles-médical, A. Gallot gave an address on Ambroise Paré as a syphilologist. It appears that Paré was the first author in the French language on syphilis, under the title, De la grosse Vérole dite maladie vénérienne et des accidents qui adviennent $\dot{a}$ icelle. The first complete edition known is dated 1575 . Of the 49 chapters, 15 deal with acquired syphilis. Others are devoted to gonorrhoea, chancroid, congenital syphilis and other more or less cognate subjects. The clinical picture of syphilis in its three stages, as presented by Paré, is very complete and the differential diagnosis well established in certain respects, but the syphilis. Paré regarded the "great pox" as a manifestation of the "wrath of God." 